\section{Control of mother-to-child transmission of infectious diseases in Brazil: progress in HIV/AIDS and failure in congenital syphilis}

\author{
Controle da transmissão vertical de doenças \\ infecciosas no Brasil: avanços na infecção pelo \\ HIV/AIDS e descompasso na sífilis congênita
}

\footnotetext{
${ }_{1}^{1}$ Faculdade de Medicina, Universidade Federal do Ceará, Fortaleza, Brasil. 2 Coordenação Estadual de DST e AIDS de São Paulo, Secretaria Estadual de Saúde, São Paulo, Brasil.

${ }_{3}$ Coordenação Municipal de DST e AIDS do Rio de Janeiro, Secretaria Municipal de Saúde, Rio de Janeiro, Brasil. 4 Faculdade de Ciências Médicas, Santa Casa de São Paulo, São Paulo, Brasil.

Correspondence A. N. Ramos Jr. Departamento de Saúde Comunitária, Faculdade de Medicina, Universidade Federal do Ceará. Rua Professor Costa Mendes 1608, 5o andar, Fortaleza, $C E$ 60430-140, Brasil.

novaes@ufc.br
}

\section{Abstract}

In Brazil, syphilis and HIV infection are considered serious public health problems. However, in practice, epidemiological surveillance, prevention measures, and prenatal care seem to be more effective in the control of mother-to-child transmission of the HIV than in the control of transmission of the Treponema pallidum. Here we discuss the differences in surveillance, prenatal care, and care of the newborn. Important differences were identified. It is concluded that there is an urgent need to establish prevention of mother-to-child transmission of syphilis as a public health priority, using an integrated approach including women's health, children's health, primary health care, and STD/AIDS programs on all governmental levels. These issues also need to be discussed with all stakeholders involved. Important aspects related to the problem are the training of public health professionals, as well as the participation of the community. The elimination of congenital syphilis does not require expensive drugs, and diagnostic tools, but a long-term sustainable approach.

Prenatal Care; Vertical Disease Transmission; Congenital Syphilis; HIV; Acquired Immunodeficiency Syndrome

\author{
Alberto Novaes Ramos Jr. ${ }^{1}$ \\ Luiza Harunari Matida 2 \\ Valéria Saraceni 3 \\ Maria Amélia de S. M. Veras 4 \\ Ricardo José Soares Pontes 1
}

\section{Introduction}

In Brazil, the successive transformations in the epidemiological profile are different character from those observed in the industrialized countries 1, where chronic-degenerative diseases are progressively replacing infectious and parasitic diseases are being progressively substituted for chronic-degenerative diseases, even though most industrialized countries have been facing the emergence and re-emergence of infectious diseases 2,3. In reality, the Brazilian epidemiological context is characterized by a morbidity/mortality subsequent to the inequality resulting from a "protracted epidemiological transition" 4.

A look at the five huge Brazilian regions shows an epidemiological situation in which important contrasts 5 are determined by a historic process of "geographic polarization", side by side with social contrasts, manifesting themselves through marked differences in the levels of morbidity/ mortality indicators among different population strata 1 .

The study of the epidemiological situation of the infection by the human immunodeficiency virus (HIV), and of the infection by the Treponema pallidum, permits the observation, and contrast, of conditions typical to both groups of diseases, respectively, called "emerging" 6,7, and "persistent" 8 . The HIV was identified in 1983 , and the first therapeutic intervention, Zidovudine (AZT), was approved for human use 
in 1987 10. Its utilization in the prophylaxis of vertical HIV transmission has had the greatest epidemiological impact so far observed in the prevention of new cases of this infection ${ }^{11}$. On the other hand, the T. pallidum was discovered in 1905 by Schaudinn \& Hoffmann ${ }^{12}$, and the antimicrobial activity of penicillin was established in 1928, with proven antibacterial effects in human beings in 194113 .

Syphilis and the HIV infection can be transmitted from mother to child, under different probabilities: approximately $25 \%$ in the case of HIV 11 , and, in the case of syphilis, from $70 \%$ to $100 \%$, in the primary and secondary phases, falling to approximately $30 \%$ in the later phases of maternal infection (latent and tertiary) 14. The reduction of mother-to-child HIV transmission and the elimination of congenital syphilis can be achieved if they are prevented and /or diagnosed and treated during the prenatal period.11,14. In the case of the HIV there is also exists the possibility of preventing HIV transmission during delivery or after birth, but this is not possible with syphilis. The rate of mother-to-child HIV transmission can be reduced to levels of less than $2 \% 15$. Congenital syphilis can now be eliminated entirely if the mother is diagnosed and treated during the prenatal period 14,16,17.

In spite of the real possibility of attaining high control levels, the reduction of mother-to-child transmission of these diseases has not occurred in an equitable manner among countries, nor even among different regions of the same country 7,18,19. Even though screening and treatment interventions have been recommended for the entire population of infected expecting mothers and their babies, there is still low coverage and quality of actions. Difficulties of the healthcare network in assisting, counseling, and making laboratory diagnoses of the infections reflect this situation. Insufficient prenatal screening coverage of women, mainly in the most vulnerable populations, and the varying quality of prenatal care, still less than desirable, result in unequal and precarious healthcare utilization in many regions 16,19 .

Therefore, mother-to-child HIV and syphilis transmission continue to be major public health challenges, demanding consistent strategies that incorporate, not only data relative to this complex infectious process, but also the behavior of the population.20,21,22. Meanwhile, analyse have shown that mother-to-child syphilis transmission in Brazil currently represents a worse health threat than that of the mother-to-child HIV infection.

From this perspective, the object of this paper is to establish an epidemiological scenario for the mother-to-child HIV and T. pallidum in Brazil, through a comparative analysis of actions in the context of epidemiological surveillance, control, prevention, and care, of these two infectious processes.

\section{Methods}

The analysis of the epidemiological scenario in Brazil was based on a review of the scientific literature and official documents about on the subject, published by the Ministry of Health, and, in particular, the Brazilian National STD/AIDS Program (PNDST/AIDS). These include, mainly, the analysis of data from the Reportable Diseases Database (SINAN), specifically for syphilis, data available in national epidemiological bulletins, as well as the results of sentinel studies of HIV and T. pallidum infection among pregnant women, financed by the Ministry of Health.

By constructing an epidemiological profile of the morbidity/mortality for the different Brazilian regions, an attempt was made to establish a relationship between a set of strategies aiming to curb the spread of such infections and the epidemiological surveillance of HIV and T. pallidum among mothers and children. In this way, published official guidelines, bulletins, and reports that document the national response to vertical transmission of these diseases were identified.

\section{Mother-to-child T. pallidum transmission scenario in Brazil}

There are still high levels of syphilis in Brazil, even in the $21^{\text {st }}$ century. This is in spite beginning of actions to reduce the mother-to-child $T$. pallidum transmission before those for HIV, and Brazil having participated in the "Project for the Elimination of Congenital Syphilis in the Americas", in 1995 23, and agreeing to an elimination goal (it still has not been achieved). Based on data from reported cases, the incidence rate in the country had varied from 0.09 cases per thousand live births in 1998 to 1.6 cases per thousand live births in 2004. 24 .

Even though reporting has been compulsory since 1986 , only 29,396 cases of congenital syphilis were reported to the Ministry of Health between January 1998 and June 2005 24. Taking as a reference the estimates of a national sentinel study of expectant mothers in 2004, substantial under-reporting. This study was carried out in a representative sample of pregnant women between 15 and 49 years of age from all regions of the country (almost 20,000 women) and indi- 
cated a $1.6 \%$ average incidence for syphilis, with approximately 50,000 pregnant women infected with the disease and an estimated 12,000 live born babies with congenital syphilis per year (using an estimated rate for mother-to-child transmission of $25 \%$ ) 24 . Based on these national data, the average under-reporting to SINAN is estimated to be of $67 \%$ a year. Therefore, the number of reported congenital syphilis cases that is used to generate the incidence rates used by the PNDST/AIDS is much lower than expected.

Corroborating these data, in a study carried out in the municipality of Rio de Janeiro, that started with a campaign to eliminate congenital syphilis and was waged between 1999 and 2000 , the under-reporting of congenital syphilis to SINAN was found to be between $60 \%$ and $70 \%$. 25.

On the other hand, the recording of syphilis during pregnancy was only required in 2005, although previous experiences had demonstrated its importance, and the possibility of leveraging prenatal control actions to reduce motherto-child transmission. It was defined that, for purposes of epidemiological surveillance, all pregnant women that presented with clinical symptoms of syphilis and/or with a positive serological result for a non-treponemic test, of any title, even in the absence of treponemic test results, carried out during prenatal care, during delivery or curettage, should be reported 24 .

The inclusion of syphilis as a compulsory, reportable sexually transmitted disease (STD) was justified, not only because of its elevated incidence rate, mainly among young adults, with a consequent high rate of mother-to-child transmission, but also because of the existence of effective control actions, low-cost diagnosis, and treatment. Another rationale was the high mortality associated with congenital syphilis, and the international commitment of the country for the elimination of this disease 23 .

The incidence rates in Brazilian regions, revealed by the sentinel study carried out in 2004 were: $1.9 \%$ in the Northeast, $1.8 \%$ in the North, $1.6 \%$ in the Southeast, $1.4 \%$ in the South, and $1.3 \%$ in the Central-West 24 , translating the regional inequalities in the country. Other studies that analyzed the specific situation of the Southern and Southeastern Regions (in the cities of Porto Alegre - Rio Grande do Sul State -, and Rio de Janeiro) showed that the maternal profile related to congenital syphilis cases in both cities was very similar, affecting women with poor socio-economic conditions, socially excluded, younger, and with a low educational level 25,26. This situation exposed existing inequalities, even within cities, and demonstrated that poverty is the common denominator that determines congenital syphilis 27 .

In a research carried out in 1999 and 2000, as part of a national sentinel study of pregnant women, the syphilis incidence rate was that of $1.7 \%$. The major identified risk factors identified for syphilis were: family income of less than one minimum wage, first sexual intercourse with less than 17 years of age, age under 14 during first pregnancy, background of syphilis or other STD during previous pregnancy, treatment for syphilis during current pregnancy, realization of VDRL (venereal disease research laboratory) testing of partner, positive anti-HIV test or test not carried out, previous premature birth, and stillborn birth as a result of pregnancy. Only $43 \%$ of the women in puerperium had six or more prenatal consultations, and only $3 \%$ had a VDRL in the first and third trimester of gestation 28 .

For the latter study it was evident that, aside from the social determinants, operational factors of the health service network of the Brazilian Unified National Health System (SUS) necessarily need to be considered. The analysis of the data from SINAN equally gave evidence of these factors: among congenital cases of syphilis reported in 2004, $78.8 \%$ of the mothers had a prenatal, $57 \%$ of these had syphilis diagnosed during pregnancy, but only $14.1 \%$ had their partners treated. Even without considering the percentage of unknown information, these indicators reflect, in operational terms, low prenatal quality in the country and/or fragility of diagnostic and treatment actions for syphilis, principally during pregnancy 24 .

On the other hand, syphilis mortality also is an important indicator for analysis. In Brazil, between 1991 and 1999, the congenital syphilis mortality rates in infants less than a year old remained stable at four deaths per 100,000 19,23. Starting in 1999, a declining trend observed, dropping to 1.7 deaths per 1000,000 live births in 200424 . In spite of a supposed improvement in care, factors such as under-reporting of cases and deaths could be masking the true values of this indicator.

From the point of view of healthcare providers, better approaches to prenatal diagnosis and care are the keys to responding to these problems. However, some situations, such as dealing with sexual partners, interpreting VDRL results, and the use of penicillin in the basic health-care network, have become, paradoxically, big challenges. In the case of penicillin, many locations in Brazil are not dispensing it, citing adverse side effects, principally anaphylaxis 29 .

To organize a structured response, a series of legal documents were defined for reorganiz- 
ing the SUS network to improve the diagnosis and treatment of syphilis, with an emphasis on pregnant women $30,31,32,33,34,35,36,37$. Among the questions covered were: humanizing prenatal care, the financing of complementary diagnostic methods for syphilis, obligatory use of VDRL in maternity wards, and the use of penicillin in the SUS network.

\section{Mother-to-child HIV transmission scenario in Brazil}

In developed countries, the implementation of interventions to reduce this form of HIV transmission, mainly the administration of antiretrovirals, elective caesarean section, and replacing of breastfeeding, have resulted in substantial reductions in the incidence of AIDS in children 38 .

In 2005, the AIDS epidemic in Brazil had more than 371,000 cases of the disease confirmed, and an estimate of around 600,000 HIV infected individuals 39 . Of the total confirmed cases, 118,520 (32\%) were in women. Between 1993 and 2004, the incidence rate per 100,000 inhabitants grew 2.7 times (from 5 to 12.5) among women, compared to 1.1 times among men (from 17.7 to 20.7 ) 24 . This increase in cases among women is a consequence of the increase of AIDS cases in men through heterosexual transmission. Since the beginning of the epidemic, sexual transmission has been responsible for $75 \%$ of AIDS cases in women, reaching 95\% in 200424 .

As a result, the spread of the epidemic in the female population has led to an increase of AIDS cases in children, who acquire it through motherto-child HIV transmission. In the case of children of both genders under five years old, a continuous decline in the number of reported cases has been observed since 1998. The decline probably reflects preventative actions and control of mother-to-child HIV transmission, which started to be effectively implemented in the second half of the 1990s $17,24,40$.

Since 2000, the reporting of pregnant women and children infected with/exposed to the HIV has been mandatory. Nevertheless, considering the poor quality of the data available from SINAN, an analysis of the situation in the country, such as, for example, a clear definition of the infection status in HIV exposed children, is not possible. This has meant that none of the Boletim Epidemiológico do SUS have been able to carry out an analysis of this database on a national level.

In the State of São Paulo, Brazil, for example, the epidemiological surveillance data indicate that in 2004 only $77.8 \%$ of the expected HIV cases in pregnant women were reported. The distri- bution of this coverage by region, nevertheless, presents an important variation (between $19 \%$ and $100 \%$ ). In addition, the prenatal use of antiretrovirals by pregnant women occurred in $69 \%$ of the cases, but in $15.8 \%$ of them this information was not made available to SINAN (Secretaria de Estado da Saúde de São Paulo. Boletim Epidemiológico do Centro de Referência e Treinamento em DST/AIDS 2005; Ano VI; no. 1). This situation demands changes in the epidemiological surveillance process on a national level for HIV-infected pregnant women and exposed children.

As a form of subsidizing national response, a surveillance study among pregnant women, carried out in 2000, demonstrated an HIV infection incidence rate of $0.47 \%$ in pregnant women 40 . Starting with these data, utilizing the birth rate for the population of fertile women, and multiplying it by the rates encountered 39 , yielded an estimated of 16,566 HIV infected women was reached. In a 2004 sentinel study, once again in a representative sample of pregnant women between 15 and 49 years of age, from all regions of the country, the HIV infection incidence rate was $0.42 \%$ at the moment of birth, which corresponded to an estimated 12,644 pregnant women infected 41 . It must be emphasized that these numbers are always lower than those encountered for syphilis.

Regarding mother-to-child HIV transmission, the first specific study published in the country showed a rate of $16 \%$ in four municipalities in the state of São Paulo ${ }^{42}$. Another study, carried out by the Sociedade Brasileira de Pediatria [Brazilian Pediatrics Society] in 2002 revealed a mother-tochild transmission rate of $3.7 \%$ for the country as a whole 43 . Based on the results of these studies it is possible to confirm an important reduction in vertical HIV transmission over the years. Even so, following the time tendency of mother-to-child HIV/AIDS transmission incidence rates, in spite of an important reduction after the introduction of antiretroviral therapy, there is still a faster spread in some areas, especially in the Northern and Northeastern Regions 24.

Other sources of national data have also been utilized. In regard to prenatal care, the data available from the National System of Prenatal Information (SISPRENATAL), introduced in 2001 as part of the Program for the Humanization of Labor and Childbirth, to monitor care for women and the newly born from the first prenatal to puerperal consultation, documents more HIV tests than VDRL tests being performed in the country, $40 \%$ vs. $9 \%$. This situation shows that the quality of prenatal care is unequal among the different Brazilian Regions, especially in the North, Northeast, and Central-West 5 . 
Even though the Brazilian healthcare network has made available all the necessary inputs for the reduction of mother-to-child transmission at public healthcare providers (anti-HIV test, antiretroviral medication, lactation inhibitor, and infant formula), a study carried out in 2003 shows that only $52 \%$ of pregnant Brazilians received effective prenatal coverage. This percentage varies from $24 \%$ among women in the Northeast, to $71 \%$ among women in the South. In addition, considering the educational level, percentages vary from $19 \%$, among illiterate women, to $64 \%$ among those that have at least full basic education. When the analysis only takes into account those pregnant women who have fulfilled all the Ministry of Health recommendations for HIV detection during pregnancy (first prenatal exam during the first trimester, six or more prenatal exams, request for anti-HIV test and results before delivery), the countrywide proportion does not exceed $27 \%$, varying from $10 \%$ in the Northeast, to $41 \%$ in the South. It must be pointed out that only $6 \%$ of illiterate women completed all the recommended stages of the process 44 .

In 2003, considering care at the moment of delivery as being strategic, the Birthing ProjectMaternity Hospitals was created, aimed at reducing by $50 \%$ the mother-to-child HIV transmission rate, from $16 \%$ to $8 \%$, among those mothers identified with a rapid test at the moment of delivery, and from $16 \%$ to less than $3 \%$ among those mothers that had had appropriate prenatal diagnosis and treatment. The proposal envisaged recovering opportunities lost during prenatal care, not only in terms of controlling congenital syphilis, but also HIV infection in exposed infants, as more than $90 \%$ of deliveries that occurred in a hospital environment. The program was implemented in SUS maternities, located in municipalities considered to be a priority, according to epidemiological criteria 44 . Meanwhile, the evaluation of this project revealed important problems in its application 24 .

Similarly to what has been done in respect to T. pallidum infection, legal documents were issued aimed at the reorganization of clinical care and management and the use of antiretroviral therapy, emphasizing HIV-infected pregnant women and the strategies for reducing motherto-child transmission $30,31,32,33,34,35,36,37$.

\section{Discussion}

The fact that there are such important differences among the responses to these two diseases in Brazil is paradoxical. In reality, the attempt to of mobilize for congenital syphilis control has not generated the same response as it happened to HIV/AIDS. In spite of campaigns to encourage the population to use condoms, these efforts further reinforce attention on AIDS, thus contributing to less attention being given to the dangers of syphilis and other STD.

Even with under-reporting, and the fact that patients, for unknown reasons, do not have access to treatment, the number of AIDS cases in children due to mother-to-child exposure has been progressively decreasing in Brazil, while at the same time congenital syphilis has been presenting a different behavior, maintaining its prevalence, and, in some regions, significantly increasing.

Important steps are upgrading the programs and perfecting epidemiological surveillance, whose objects are early detection during the course of gestation, and the implementation of measures that avert the transmission of both $T$. pallidum, in the case of syphilis, and HIV, in the case of AIDS, thus avoiding the appearance of new cases.

More specifically, to reach these objectives it is necessary to: (1) carry out early diagnoses of HIV and syphilis infections, facilitating the prompt institution of treatment for the women and their partners, which aids the short, medium, and long term prognosis of the disease, aside from the interrupting the various forms of transmission, with the adoption of preventative measures; (2) diagnoses of HIV and T. pallidum infections, starting by giving the woman the opportunity to be counseled, followed up by a multi-professional team, so that they will be able to understand their actual situation, encouraging compliance to approved measures; (3) begin prophylaxis protocols for mother-to-child HIV and syphilis transmission as early as possible, thus guaranteeing the best outcome for the babies.

It must again be re-emphasized that public healthcare services should make available all necessary inputs for prophylaxis of mother-tochild transmission available. As the diagnosis is made, in most cases, during prenatal exams, the difference in implementation of programs will be reflected in the effectiveness of actions, due to the infra-structure in terms of follow-up and access to healthcare services.

After the serologic diagnostics, offered in an unequal manner for the two diseases, with the anti-HIV testing linked to counseling, female carriers of HIV are almost always referred to more sophisticated healthcare services, where they are submitted to protocols that have been well established by the PNDST/AIDS 45. Women diagnosed with syphilis, in general, have their follow-up at basic healthcare services, and in 
spite of the existence of concrete recommendations for the treatment of this disease during pregnancy 46,47 , cases of congenital syphilis remain at levels which are far from any goal for eliminating congenital syphilis in the foreseeable future. Therefore, a strengthening resolution in basic healthcare is needed, considering that the presence/absence of congenital syphilis is an important indicator for the management of the healthcare service network 47 .

Another question is the fact that antiretrovirals are administered orally, which implies in an educational effort to guarantee the necessary compliance among the women over the whole gestational period. Syphilis is still treated with benzathine penicillin, the only medication proven to be effective in treating both mother and fetus $46,47,48$, and which should be administered throughout the whole SUS network. Moderate allergic reactions to penicillin are rare 0.5 to 1 case per thousand treatments) 49 , transformed into an eventual risk of death for one in 100,000 people who receive the medication 29,50 . In this situation, the quality of the health professional is of overwhelming importance.

Another difference, however, resides in the possibility of late intervention, even at the moment of delivery, to avoid mother-to-child HIV transmission. If the pregnant woman is identified at the moment of delivery, or even post-delivery, as an HIV-infected woman, there is still time to administer prophylaxis with injected AZT and withhold breastfeeding, which impedes around $75 \%$ of vertically transmitted cases 11,15.

In the case of syphilis, a diagnosis during labor or in the puerperium does not prevent congenital syphilis, and so the newborn will have to undergo a ten day treatment with procaine or crystalline penicillin, depending on the severity of the infection 47,48 . In addition, syphilis untreated during gestation results in a fetal, and early neonatal, death rate of approximately $40 \%$ $47,51,52$, further aggravating the epidemiological situation of syphilis in the country, aside from being a tragedy for the families affected.
To sum up, vulnerability contexts, based on different susceptible populations, and low socio-economic levels, are aspects that should be viewed together in an operational context for the healthcare services network to develop actions against both syphilis and HIV infections.

\section{Conclusions}

At the beginning of the $21^{\text {st }}$ century there are still many children suffering from congenital syphilis, not only in Brazil, but in other parts of the world 17,18, despite the positive and effective confrontation of mother-to-child HIV transmission 53,54,55.

Although strategies for eliminating motherto-child HIV transmission and congenital syphilis are being focused on the prenatal care period, it is evident that their implementation is diferent in the different regions of Brazil.

For this needed response, the construction of integral management and care is considered fundamental, not only in the dimension of healthcare by professionals, but also in the organization of healthcare services and the structuring of public policies 56. Questions such as the proper training of health professionals, the re-orientation of control actions of the public healthcare network in the benchmark of health surveillance, and in the application of the legal instruments being prepared, mainly in the past five years, have become a challenge.

Therefore, in the face of epidemiologically expressed inequality in these two conditions, the priority to focus on syphilis in pregnant women, along with mobilization of the entire society, has become necessary and urgency. The emphasis on congenital syphilis as being a sentinel event in public health must be re-enforced 47 . In regard to HIV infection, forces should be maintained and perfected, with the purpose of achieving reduced transmission levels that are comparable to those of the developed nations 45,53 . 


\section{Resumo}

No Brasil, a infecção pelo Treponema pallidum e pelo vírus da imunodeficiência humana são eventos considerados prioritários. No entanto, apesar das políticas públicas, a resposta em termos das ações de vigilância e prevenção, assistência pré-natal e ao recém-nascido, é diferenciada, parecendo ser mais bem estruturada para a redução da transmissão vertical do HIV do que para a do T. pallidum. No presente artigo, potenciais diferenças são analisadas quanto ao desenvolvimento das ações. Identificou-se que as desigualdades existentes na atenção aos dois problemas apresentam dimensões diferenciadas nas regiões do país. Reconheceu-se a necessária e urgente priorização da sífilis na gravidez, envolvendo áreas técnicas como atenção básica, saúde da mulher, saúde da criança e controle de doenças sexualmente transmissíveis, em todas as esferas de governo. Emerge como questão relevante no encaminhamento do problema a formação de profissionais de saúde e a mobilização da sociedade na perspectiva do controle. É ainda necessário inserir o tema e formas de enfrentamento na agenda de gestão. A eliminação da sífilis congênita requer insumos de baixo custo, bem como ações sustentáveis em longo prazo.

Cuidado Pré-Natal; Transmissão Vertical de Doença; Sífilis Congênita; HIV; Síndrome de Imunodeficiência Adquirida

\section{References}

1. Araújo J. Polarização epidemiológica no Brasil. Inf Epidemiol SUS 1992; 1:5-16.

2. Luna EJA. A emergência das doenças emergentes e as doenças infecciosas emergentes e reemergentes no Brasil. Rev Bras Epidemiol 2002; 5:229-43.

3. Carmo EH, Barreto ML, Silva Jr. JB. Mudanças nos padrões de morbi-mortalidade da população brasileira: os desafios para um novo século. Epidemiol Serv Saúde 2003; 12:63-75.

4. Frenck J, Frejka T, Bobadilla J, Stern C, Lozano $\mathrm{R}$, Sepúlveda J. La transición epidemiológica en América Latina. Bol Oficina Sanit Panam 1991; 111:485-96.

5. Ministério da Saúde. Saúde Brasil 2004: uma análise da situação de saúde. Brasília: Ministério da Saúde; 2004.

6. Satcher D. Emerging infections: getting ahead of the curve. Emerging Infect Dis 1995; 1:1-6.

7. Morse S. Factors in the emergency of infectious diseases. Emerging Infect Dis 1995; 1:7-15.

8. Barreto ML, Carmo EH, Noronha CV, Neves RBT, Alves PC. Mudança nos padrões de morbi-mortalidade: uma revisão crítica das abordagens epidemiológicas. Physis (Rio J) 1993; 3:126-46.

\section{Contributors}

A. N. Ramos Jr. and L. H. Matida were responsible for creating the proposal, reviewing the literature, and writing and editing the article. V. Saraceni, M. A. S. M. Veras and R. J. S. Pontes participated in the literature review and writing and editing the article.
9. Barre-Sinoussi F, Chermann JC, Rey F, Nugeyre MT, Chamaret S, Gruest J, et al. Isolation of a T-lymphotropic retrovirus from a patient at risk for acquired immune deficiency syndrome (AIDS). Science 1983; 220:868-71.

10. Fischl MA, Richman DD, Grieco MH, Gottlieb MS, Volberding PA, Laskin OL, et al. The efficacy of azidothymidine (AZT) in the treatment of patients with AIDS and AIDS-related complex: A doubleblind, placebo-controlled trial. N Engl J Med 1987; 317:185-91.

11. Connor EM, Sperling RS, Gelber R, Kiselev P, Scott G, O'Sullivan MJ, et al. Reduction of maternal-infant transmission of human immunodeficiency virus type 1 with zidovudine treatment. Pediatric AIDS Clinical Trials Group Protocol 076 Study Group. N Engl J Med 1994; 331:1173-80.

12. Souza EM. Há 100 anos, a descoberta do Treponema pallidum. An Bras Dermatol 2005; 80:547-8.

13. Fleming A. On the antibacterial action of cultures of a penicillium, with special reference to their use in the isolation of B. influenzae. Br J Exp Path 1929; 10:226-36. 
14. Berman SM. Maternal syphilis: pathophysiology and treatment. Bull World Health Organ 2004; 82:433-8.

15. Mofenson LM, Munderi P. Safety of antiretroviral prophylaxis of perinatal transmission for HIV-infected pregnant women and their infants. J Acquir Immune Defic Syndr 2002; 30:200-15.

16. Ministério da Saúde. Bases técnicas para a eliminação da sífilis congênita. Brasília: Coordenação Nacional de DST e AIDS, Ministério da Saúde; 1993.

17. Peeling RW, Mabey D, Fitzgerald DW, Watson-Jones D. Avoiding HIV and dying of syphilis. Lancet 2004 364:1561-3.

18. Hook EW, Peeling RW. Syphilis control: a continuing challenge. N Engl J Med 2004; 351:122-4.

19. Lima BGC. Mortalidade por sífilis nas regiões brasileiras 1980-1995. J Bras Patol Med Lab 2002; 38:267-71.

20. Joint United Nations Programme on HIV/AIDS/ World Health Organization. Guidelines for second generation HIV surveillance: the next decade. Geneva: Joint United Nations Programme on HIV/ AIDS/World Health Organization; 2000.

21. De Lorenzi DRS, Madi JM. Sífilis congênita como indicador de assistência pré-natal. Rev Bras Ginecol Obstet 2001; 23:647-52.

22. Gardella C. Sexually transmitted infections in pregnancy: treatment options. Current Treatment Options in Infectious Diseases 2003; 5:53-61.

23. Ministério da Saúde. Projeto de eliminação da sífilis congênita. Brasília: Coordenação Nacional de DST e AIDS, Ministério da Saúde; 1997.

24. Ministério da Saúde. Boletim Epidemiológico AIDS e DST 2005; Ano II; n. 1.

25. Saraceni V, Vellozo V, Leal MC, Hartz ZMA. Estudo de confiabilidade do SINAN a partir das Campanhas para a Eliminação da Sífilis Congênita no Município do Rio de Janeiro. Rev Bras Epidemiol 2005; 8:419-24.

26. Lago EG, Rodrigues L, Fiori RM, Stein AT. Congenital syphilis: identification of two distinct profiles of maternal characteristics associated with risk. Sex Transm Dis 2004; 31:33-7.

27. Saraceni V, Leal MC. Avaliação da efetividade das campanhas para eliminação da sífilis congênita na redução da morbi-mortalidade perinatal: Município do Rio de Janeiro, 1999-2000. Cad Saúde Pública 2003; 19:1341-9.

28. Rodrigues CS, Guimarães MDC; Grupo Nacional de Estudo sobre Sífilis Congênita. Positividade para sífilis em puérperas: ainda um desafio para o Brasil. Rev Panam Salud Pública 2004; 16:168-75.

29. Prefeitura Municipal de São Paulo, Secretaria Municipal de São Paulo, Coordenação de Desenvolvimento da Gestão Descentralizada. Instrução técnica para a prescrição e a utilização de penicilinas e prevenção da sífilis congênita. São Paulo: Prefeitura Municipal de São Paulo, Secretaria Municipal de São Paulo, Coordenação de Desenvolvimento da Gestão Descentralizada; 2004.

30. Brasil. Portaria no. 9. Estabelece o processo de adesão ao Programa de Humanização no Pré-Natal. Diário Oficial da União 2000; 5 jul.
31. Brasil. Portaria no ${ }^{\circ}$ 822. Inclui na tabela de procedimentos especiais do Sistema de Informações Hospitalares do SUS (SIH/SUS), dentre outros, a micro-hemaglutinação para o diagnóstico da sífilis. Diário Oficial da União 2003; 27 jun.

32. Brasil. Portaria SAS/MS no. 766. Torna obrigatória a execução do VDRL nas maternidades, tendo sua vigência redefinida a partir de março de 2005 (Portaria SAS/MS nº. 124, de 1 de março de 2005). Diário Oficial da União 2004; 21 dez.

33. Brasil. Portaria MS 156. Dispõe sobre o uso da penicilina na atenção básica à saúde e nas demais unidades do Sistema Único de Saúde (SUS). Diário Oficial da União 2006; 19 jan.

34. Brasil. Lei $n^{\circ}$. 9.313. Dispõe sobre a distribuição gratuita de medicamentos aos portadores do HIV e doentes com AIDS. Diário Oficial da União 1996; 13 nov.

35. Brasil. Portaria ${ }^{\circ}$. 874. Define as competências específicas para o manejo da infecção pelo HIV e da AIDS. Diário Oficial da União 1997; 3 jul.

36. Conselho Federal de Medicina. Resolução no 1.665. Referenda o tratamento médico das pessoas vivendo com o HIV/AIDS. Conselho Federal de Medicina 2003, 7 mai.

37. Brasil. Portaria $n^{\circ}$. 1.071. Disponibiliza a fórmula infantil para crianças expostas ao HIV durante os seis primeiros meses de vida. Diário Oficial da União 2003; 9 jul.

38. Centers for Disease Control and Prevention. U.S. public health service recommendations for human immunodeficiency virus counseling and voluntary testing for pregnant women. MMWR Recomm Rep 1995; 44:1-15.

39. Szwarcwald CL, Carvalho MF. Estimativa do número de indivíduos de 15 a 49 anos infectados pelo HIV, Brasil, 2000. Boletim Epidemiológico de AIDS 2001; Ano XIV; n ${ }^{\circ}$. 1. p. 35-40.

40. Ministério da Saúde. Vigilância do HIV no Brasil: novas diretrizes. Brasília: Coordenação Nacional de DST e AIDS, Ministério da Saúde; 2002.

41. Szwarcwald CL. Relatório: primeiros resultados do Estudo-Sentinela Parturiente 2004. Brasília: Programa Nacional de DST e AIDS, Ministério da Saúde; 2004 .

42. Tess BH, Rodrigues LC, Newell ML, Dunn DT, Lago TD. Breastfeeding, genetic, obstetric and other risk factors associated with mother-to-child transmission of HIV-1 in São Paulo State, Brazil. São Paulo Collaborative Study for Vertical Transmission of HIV-1. AIDS 1998; 12:513-20.

43. Succi RCM; Grupo de Estudos da Sociedade Brasileira de Pediatria. Transmissão vertical do HIV no Brasil em 2003-2004: resultado preliminar de um estudo colaborativo multicêntrico. In: XIV Congresso Brasileiro de Infectologia Pediátrica e III Jornada Paranaense de Infectologia Pediátrica. Recife: Sociedade Brasileira de Pediatria; 2006. p. S100.

44. Souza Júnior PRB, Szwarcwald CL, Barbosa Júnior A, Carvalho MF, Castilho EA. Infecção pelo HIV durante a gestação: Estudo-Sentinela Parturiente, Brasil, 2002. Rev Saúde Pública 2004; 38:764-72. 
45. Ministério da Saúde. Recomendações para profilaxia da transmissão vertical do HIV e terapia antiretroviral em gestantes. Brasília: Programa Nacional de DST e AIDS, Ministério da Saúde; 2006.

46. Ministério da Saúde. Manual de doenças sexualmente transmissíveis. Brasília: Programa Nacional de DST e AIDS, Ministério da Saúde; 2005.

47. Ministério da Saúde. Manual de sífilis congênita. Brasília: Programa Nacional de DST e AIDS, Ministério da Saúde; 2005.

48. Walker GJA. Antibiotics for syphilis diagnosed during pregnancy. (Cochrane Review). In: The Cochrane Library, Issue 4, 2006. Oxford: Update Software.

49. Ministério da Saúde. Testes de sensibilidade à penicilina - manual. Brasília: Coordenação Nacional de DST e AIDS, Ministério da Saúde; 1999.

50. Levine BM, Smith JL, Martinez SA, Montenegro EN, Nicol WG. VDRL test in normal albino and pigmented rabbits. Br J Vener Dis 1969; 45:197-9.

51. Saraceni V, Guimarães MHSF, Theme Filha MM, Leal MC. Mortalidade perinatal por sífilis congênita: indicador da qualidade da atenção à mulher e à criança. Cad Saúde Pública 2005; 21:1244-50.
52. Peeling RW, Ye H. Diagnostic tools for preventing and managing maternal and congenital syphilis: an overview. Bull World Health Organ 2004; 82:43946.

53. Ministério da Saúde. Response Magazine +2005 : experiences of the Brazilian AIDS programme. Brasília: Programa Nacional de DST e AIDS, Ministério da Saúde; 2005.

54. Grangeiro A, Ferraz D, Barbosa R, Barreira D, Veras MASM, Villela W, et al. UNGASS-HIV/AIDS: balanço da resposta brasileira, 2001-2005. Rev Saúde Pública 2006; 40:5-8.

55. Ministério da Saúde. Plano estratégico do Programa Nacional de DST e AIDS. Brasília: Programa Nacional de DST e AIDS, Ministério da Saúde; 2005

56. Pinheiro R, Mattos RA, organizadores. Construção da Integralidade: cotidiano, saberes e práticas em saúde. Rio de Janeiro: Universidade do Estado do Rio de Janeiro/ABRASCO; 2003.

Submitted on $21 / \mathrm{Jul} / 2006$

Final version resubmitted on 01/Nov/2006

Approved on 13/Nov/2006 